\title{
Listen to What Doctors Say: Discursive Authority in Two Persian Medical Publications
}

\section{Seyyed-Abdolhamid Mirhosseini, Alzahra University, Iran}

\begin{abstract}
With a concern for social relations of power and authority and referring to the role of discourse in constructing and legitimating worldviews, perceptions, and practices, this study investigates particular instances of medical discourse in two distinct types of print medical media. Two sets of articles shape the overall bulk of data investigated in this research. The first set comprises 20 articles selected from Salamat medical journal which is a weekly publication aimed at the general non-expert public. The second body of data is shaped by 20 other articles appearing in Pezeshky-e Emrooz, a weekly publication specifically addressing medical practitioners. van Leeuwen's (2008) conception of 'the discursive construction of legitimation' was adopted as the general guiding framework. His particular category of Expert authority - as the type of legitimation that is based on expertise which may be explicitly stated or may be taken for granted if the expert is recognized in a particular context - was used to code the data in search of themes that represent this kind of authority within the two categories of discourse. On this basis, varying degrees of legitimation appears to be practiced within the discourse of medical professionals in these two distinct discursive arenas.
\end{abstract}

Keywords: medical discourse - critical discourse studies - legitimation strategies - Persian language medical publications 


\section{Introduction}

Critical approaches to discourse studies are based on the generally accepted assumption that repeated encounters with specific discursive practices lead to certain generalizations and reproduce social relationships, including relationships of power and authority (Fairclough, 1989; Jager, 2001; van Dijk, 1995, 2004;). Discourses construct discursive situations in a way that, to understand the discourse, interpreters would have to take certain assumptions as given. Therefore, the audience of discourses derive embedded assumptions "from the repetitive 'discourse contexts' into which they are born and involved" (Jager, 2001: 33) and, when naturalized, these assumptions acquire the status of stabilized social representations and attitudes (Fairclough, 1989; van Dijk 2004; Wodak, 2001).

A focal aspect of critical discourse studies (CDS) is the investigation of media discourse. Media in general and print media in particular are major discourses dealt with in many landmark works in discourse studies (e.g. Fairclough, 1989). In Iran CDS has been attracting increasing attention in recent years - mostly as versions of Critical Discourse Analysis. CDS research has been reported to investigate issues such as 'ideology and textualization strategies' (Mousavi, 2004); the discourse of 'socio-political changes of the Islamic revolution' (Sultani, 2005); and 'otherness' in the 'discourse on democracy' (Gheitury and Dehghan 2005). A number of critical explorations of sociopolitical constructs in advertisements and commercials in various contexts have also been reported (Babaii and Ansary, 2003; Amouzadeh, 2002, 2003).

More specifically related to the discourse genre explored in this study, an overview of studies discourse on different aspects of the discourse of health and medicine shows that Adolphs et al. are well justified to evaluate the volume of research in this area as 'phenomenal' (2004: 10). A major body of this phenomenal trend focuses on the so called medical encounters and includes descriptive or critical examinations of the communication between doctors and patients (e.g., Ainsworth-Vaughn 1998, 2003; Cordella 2004; Gotti and Salager-Meyer 2006; Gulich 2003; Mishler 1984). Many of these studies tend to situate the discourse of medical communication within a broader social context (e.g., Fisher and Todd 1983, 1993; Shaw and Greenhalgh 2008). 
Further expanding the social concern some critically oriented research on medical discourse, explicitly referring to a critical standpoint or implicitly adopting critical analytical procedures, have sometimes focused on the ideological and even political underpinnings of medical discourse (Waitzkin 1989, 1993; MacDonald 2002). With a similar concern for social relations of power and authority and referring to the role of discourse in constructing and legitimating worldviews, perceptions, and practices (Fairclough 1989; Jager 2001; van Dijk 2004), in this study we investigate two particular instances of medical discourse in two distinct types of print (medical) media.

\section{The Study}

\section{Data}

Two sets of articles shape the overall bulk of data investigated in this research. The first set comprises 20 articles selected from Salamat medical journal (www.salamat.ir). The journal is a weekly publication aimed at the general non-expert public. The articles are written by medical doctors who are mainly specialists and in many cases they are faculty members of medical universities from around the country. Some of the authors have administrative responsibilities, too. The brief articles in this weekly publication cover almost all areas of issues in public health and medicine. The 20 articles were selected from about 50 issues of the journal published in 1388 (March 2009 - March 2010). The selection was almost random and the only tentative criterion was to select from journal issues spread throughout the year and to cover as diverse a range of medical issues as possible.

The second body of data is shaped by 20 other articles appearing in Pezeshky-e Emrooz (www.pezeshkyemrooz.com ). It is a weekly publication specifically addressing general medical practitioners. Therefore, the articles are considered as written by experts for an audience of experts. Like the Salamat articles, these texts were selected from about 50 issues of the journal published in 1388 (March 2009 - March 2010) and the selection was made in way to tentatively represent journal issues throughout the year and to cover as diverse a range of medical issues as possible.

\section{Analysis}

To analyze the data within a CDS approach, van Leeuwen's (2008) conception of 'the discursive construction of legitimation', was adopted as the general guiding framework. 
Considering legitimation as justifications about the reasons why "a social practice or some part of it must take place, or must take place in the way that it does" (p. 20), van Leeuwen argues that discourses legitimate social practices besides representing them. He presents a broad model of four major and several minor categories of legitimation. The legitimation of the discursive practices in these two print media context appears to be a central aspect of the understanding of these discourses by their respective intended audience.

Of particular relevance to this study is van Leeuwen's proposed legitimation category of Authorization that refers to "legitimation by reference to the authority of tradition, custom, law, and/or persons in whom institutional authority of some kind is vested" (p. 105). Authorization is subcategorized into six types of authority: Personal, Expert, Role Model, Impersonal, Tradition, and Conformity. The particular category of Expert authority seems to be the most directly relevant category in the present study. van Leeuwen's general conception of discursive construction and legitimation of Expert authority refers to the type of legitimation that is based on expertise which may be explicitly stated or may be taken for granted if the expert is recognized in a particular context (van Leeuwen, 2008). This general conception was used to code the data in search of themes that represent this kind of authority within the two categories of discourse.

\section{Findings and Discussion}

\section{'Salamat'}

The articles in Salamt included six categories of discursive practicing of authority. Each one of these categories shaped one aspect of the discursive construction and legitimation of 'expert authority' as a central category in van Leeuwen's (2008) framework discussed above. The following is a detailed description and illustration of the six categories of discursive construction of authority in Salamat, as a medical journal addressing the general public audience.

\section{Titles}

The first category is shaped by titles such as specialist, faculty member, surgeon, professor, etc. Even the very simple word doctor appearing as the title of almost all authors of articles in this journal, seems to carry some load of shaping discursive authority. The following are examples of this category, with a frequency of 14 , in the data under investigation: 


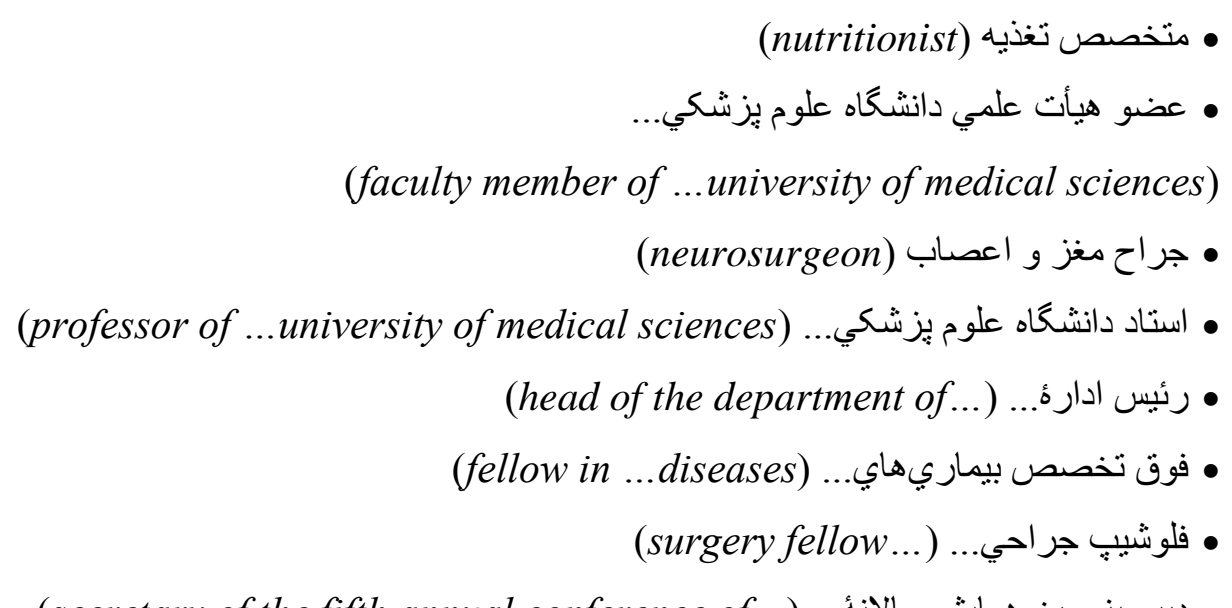

• (secretary of the fifth annual conference of...) .... دبير ينجمين همايش سالانئ

\section{Imperatives}

The most frequent category of discursive exercise of authorities in these articles is the category of using imperative structures. These forms mostly happen in the form of expert advice and, therefore, show an obvious case of expert authority. As shown in the following examples this category includes imperatives such as avoid, reduce, prevent, etc. This most frequent category occurred 62 times in the bulk of Salamat articles under investigation:

• مسألكَ... را جدي بكيريد (Take the problem of... seriously)

• مصرف روغنهاي حيو اني را كاهش دهيد (Reduce animal fat consumption) • از اسيدهاي جرب تر انس يرهيز كنيد (Avoid Trans Fatty Acids)

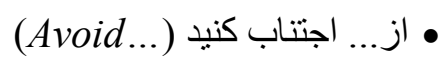

• از مصرف مكملهاي... بير هيزيد (Refrain from the consumption of ...complements)

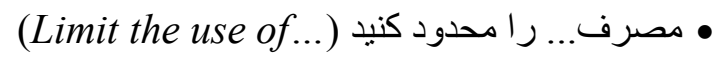
• از روغن هاي دار اي حلقههاي اشباع نشده اجتناب كنيد

(Avoid using fats with unsaturated cycles) • تلاش كنيد با توجه به جنين زخمهايي از بروز و يا كسترش سرطان بيشكيري نماييد

(Try to prevent the occurrence or development of caner by paying attention to such wounds) • در صورت بروز جنين علامني بلافاصله به نزديكترين اورز انس مر اجعه كنيد

(Immediately refer to the nearest Emergency department in the case of such signs) • به هيج وجه برنامة خود را همانند ديكر مبتلايان اجر ا نكنيد (Never follow the plans prescribed for other patients) 


\section{Must(not)}

A less frequent category of indirect imperatives is shaped by the use of must or must not structures. These structures may also be considered as a subcategory of the previous category. Structures like must be carried out and must not be done happened 17 times in the corpus of data investigated in this study. The following are examples of this category:

$$
\begin{aligned}
& \text { • • ....must not use too mush dairy products ( نبايد در مصرف لبنيات افر اط كنند : } \\
& \text { • آزمايشات مكرر قند خون در آنها بايد... انجام شود }
\end{aligned}
$$

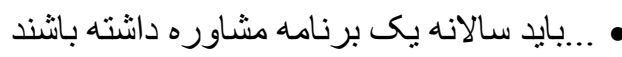

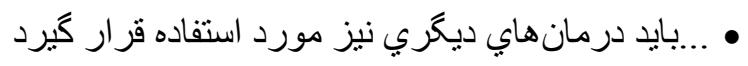

(...other therapies should also be applied)

\section{We say}

An interesting case of the exercise of expert authority through a simple discursive tool is the use of first person singular or plural as the reference of certain practices, questions, or advice. We advise, we prefer, I would say, etc. are examples of this category of discursive practice of expert authority that occurred 9 times in the data:

• ما در ابتدا به بانو ان عزيز توصيه ميكنيم كه... (We first advise the ladies to...

$$
\text { • ترجيح ميدهيم كه ابتدا درمان ها به طور كامل انجام شود.... }
$$

(We prefer to complete the treatment period first and...)

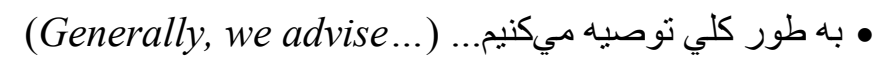
• من در مقابل همة اصر ارها عادت ندارم بيش از نهايتاً دو قلم دارو بنويسم

(Despite the insistence, I am not in the habit of prescribing more than two types of medicine)

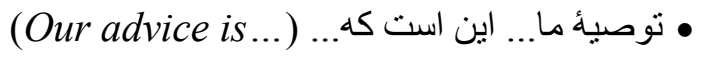

\section{Doctors say}

A related type of reference to the expert position of doctors as the sources of certain kind of expertise and advice is directly referring to terms like experts and physicians. The underlying notion is that these authorities are accepted as the source of expert knowledge. This category of discursive construction of expert authority, exemplified below, has a frequency of 13 in the twenty articles of Salamat that were explored in this study:

$$
\text { • توصيههاي شخصي را از متخصص تغذيه و مشاور رزيم غذايي خود بكيريد }
$$


(Ask for the personal advice of your nutritionist and nutrition counselor)

• بزئشان توصيه ميكند.... (Doctors advise to...

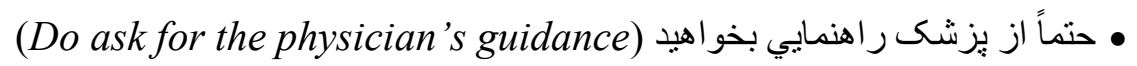

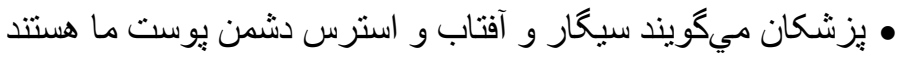

(Doctors say smoking, sunlight, and stress are the enemies of the skin)

(...consult the psychiatrist) • •

\section{Notice that}

A further type of discursive construction and legitimation of medical expert authority in these articles is indirect statements implying the previous four types of categories. This miscellaneous category is shaped by the use of some twisted forms of using imperatives and reference to expert sources of knowledge. Cases of this category appear at 31 instances throughout the twenty articles of concern:

• شايد بهتر باثند بدانيد كه... (It may be better for you to know that...)

• يادنان باشد كه... (Bear in mind that ...

• سلنيو فر اموش نشود (Selenium should not be forgotten) • بكذاريد در همين ابتداي كار... بكويم كه... (Let me say at the beginning that... • البته درستش اين است كه.... (Of course the right way is to... • مردم بر اين باورند كه.... در حالي كه اين تصور غلط است

(People believe that... but this belief is wrong) • بايد دقت كنند و بدانند كه... (...they need to be careful and to know that . • ميدانم حتما ميبرسيد جر ا؟ ( I know you ask why...)

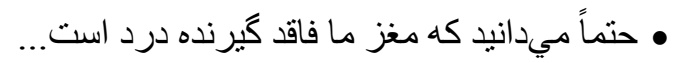

(You must know that our brain lacks pain receptors...) • سعي كنيد تاو عدة بعدي جيزي نخوريد. فرصت خوردن از شما سلب نخو اهد شد! (Try not to eat until the next meal. You will not be robbed of the eating opportunity!)

\section{'Pezeshky-e Emrooz'}

The articles of Pezeshky-e Emrooz, unlike those of Salamat, address physicians and therefore, are almost bereft of any instance of the categories of discursive construction and legitimation of expert authority illustrated above. Of course, titles, do appear in these articles, too, but given the fact that the audience themselves possess these titles, the authority construction function of these titles are negligible. 
There are two types of discursive practices that might be considered as somehow, at least marginally aimed at exercising expert authority. The first category is the use of English terms within the Farsi texts; terms such as genome-wide linkage, Immune-mediated, Leftventricular assist device, daptomycin, Autoimmune Rsponse, Neuro Muscular Tension, Uric Acid Disorder, Calcification, etc. The second category is the use of abbreviations that may be demanding in terms of expert knowledge: HIT, PF4, CABG, SSRI, etc. However, the degree of expert authority construction by these two strategies cannot be considered as very high. Probably almost all doctors use the technical terminology of medicine in English, even within their Farsi discourse. Moreover, the challenge of abbreviations cannot be considered very much for many medical doctors.

Therefore, the only discursive category of constructing some level of expert authority within the discourse of Pezeshky-e Emrooz articles investigated in this study is referencing. Authors of these articles repeatedly refer to journals, studies, countries, etc. that may be understood as attempts at constructing expert authority even in the context of an audience who are experts themselves. Instances of such discursive exercises of expert authority appear 14 times in the corpus of twenty articles from Pezeshky-e Emrooz. The following are examples of such references:

$$
\text { • در بازبيني Cochrane سال } 2008 \text { كفته شده بود.... }
$$

(It was said in the Cochrane Review of 2008 that ...) • •linical Radiology كه در انكليس منتشر ميشود......... (In 1984, in an article published in Clinical Radiology published in England...) (The results of a meta-analysis show that ...).... نتايج يك متآناليز نشان ميدهان

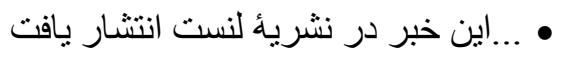
(...this news has been published in Lancet journal) • در يك بررسي روي آمار ثبت شده در دانمارك كه به كنترل استعمال دخانيات و سن مادر برداخته شده بود..... In an investigation of the statistics related to smoking control and maternal age in ) (Denmark... • يزّو هشكران آلماني ميز ان فراو اني و بيماري هاي همر اه با بِوريازيس جو انان را مورد ارزيابي قرار دادهاند German researchers studied the types and frequency of diseases accompanying Psoriasis in ) (the youth

$$
\text { • بِ از بازبيني مقدماتي توسط كمينهُ فر آورده هاي دارويي براي مصرف انسان در ارويا... }
$$

(After initial review by the Committee for Medical Products for Human Use in Europe...) 


\section{Conclusion}

With a general view of different categories of discursive legitimation of expert authority (van Leeuwen, 2008) illustrated above, varying degrees of legitimation appears to be practiced and cultivated within the discourse of medical professionals in these two distinct discursive arenas. The tacitly consented concept of hierarchy among different levels of medical professionals, as evidenced in Iran in particular (Mirhosseini and Fattahi, 2010), is the single most important factor for directing medical experts of different levels to resorting to various legitimating practices encountering various audiences.

Addressing lower levels of the hierarchy, medical experts mostly rely on expert and personal authority using titles (e.g. doctor or faculty member), different types of imperatives, self (expert) references, etc. (as shown in the excerpts from Salamat as an instance of discourse in which the high authority experts address the low authority non-experts). In this regard, legitimation is practiced quite intentionally with the power being at the hand of the medical experts.

However, addressing same or higher levels of the medical hierarchy, medical experts have to resort to other authority strategies that are accepted to be higher than the audience who are experts themselves. Therefore, as illustrated above Pezeshky-e Emrooz, doctors practice legitimation through sources of authority beyond the simple medical expert authority. Alternatively in many cases their discourse in this context remains highly neutral and they appear to avoid the exercise of authority as such. Since in the legitimation practices of this kind medical experts have to remain neutral or engage in a rather fierce competition in order to stand out in the discursive construction of legitimation. 


\section{References}

Adolphs, S., Brown, B., Carter, R. Crawford, P. and Sahota, O. (2004). Applying corpus linguistics in a health care context. Journal of Applied Linguistics 1(1): 9-28.

Ainsworth-Vaughn, N. (1998). Claiming power in doctor-patient talk. New York: Oxford University Press.

Ainsworth-Vaughn, N. (2003). The discourse of medical encounters. In D. Schiffrin, D. Tannen, and H. Hamilton (Eds). The handbook of discourse analysis (pp. 453469).Oxford: Blackwell.

Amouzadeh, M. (2002). Social realities in Persian advertising. The Linguistic Association of Korea Journal 12: 179-209.

Amouzadeh, M. (2003). Symbolic value of English language in Persian advertising. International Journal of Communication 13: 197-222.

Babaii, E. and Ansary, H. (2003). The discourse structure of and sociopolitical strictures on TV commercials. Asian EFL Journal, 5(3), September 2003. Retrieved October 22, 2004 from http://www.asian-efl-journal.com/sept_03_sub6.php

Cordella, M. (2004). The dynamic consultation: A discourse analytical study of doctorpatient communication. Amsterdam: John Benjamins.

Fairclough, N. (1989). Language and power. London: Longman.

Fisher, S. and Todd, A. (Eds.). (1983). The social organization of doctor-patient communication. Washington, DC: Center for Applied Linguistics.

Fisher, S. and Todd, A. (Eds.). (1993). The social organization of doctor-patient communication (2nd ed.). Norwood, NJ: Ablex.

Gheitury, A. and Dehghan, M. (2005). Discourse and otherness: A critical study of the other in the recent discourse on democracy. Paper presented at International Conference on Critical Discourse Analysis: Theory into Research, University of Tasmania, Australia.

Gotti, M. and Salager-Meyer, F. (Eds.). (2006). Advances in medical discourse analysis: Oral and written contexts. New York: Peter Lang.

Gülich, E. (2003). Conversational techniques used in transferring knowledge between medical experts and non-experts. Discourse Studies 5(2): 235-263.

Jager, S. (2001). Discourse and knowledge: Theoretical and methodological aspects of a critical discourse and dispositive analysis. In R. Wodak. \& M. Meyer (Eds.), Methods of Critical Discourse Analysis (pp. 32-62). London: Sage. 
MacDonald, M. N. (2002). Pedagogy, pathology and ideology: The production, transmission and reproduction of medical discourse. Discourse and Society 13(4): 447-467.

Mirhosseini, S. A. \& Fattahi, H. (2010). The language of 'circule': Discursive construction of false referral in Iranian teaching hospitals. Medical Anthropology Quarterly, 24(3), 304-325.

Mishler, E. (1984). The discourse of medicine: Dialectics of medical interviews. Norwood, NJ: Ablex.

Mousavi, S. A. (2004). Critical discourse analysis: Relationships between ideology and textualization strategies. Unpublished MA Dissertation, University of Tabriz, Iran.

Shaw, S. E. and Greenhalgh, T. (2008). Best research - for what? Best health - for whom? A critical exploration of primary care research using discourse analysis. Social Science and Medicine, 66: 2506-2519.

Sultani, A. A. (2005). A discourse analysis of the socio-political changes of the Islamic revolution 1979-2003. Paper presented at the 9th International Pragmatics Conference. Riva del Garda, Italy.

van Dijk, T. (1995). Ideological discourse analysis. In E. Ventola \& A. Solin (Eds.), New Courant, Special issue Interdisciplinary Approaches to Discourse Analysis (pp. 135161). English Department, University of Helsinki.

van Dijk, T. (2004). Ideology and discourse analysis. Oxford Symposium on Ideology. Retrieved December 11, 2004, from http://www.discourse-insociety.org/Ideology\%20and\%20 discourse\%20analysis.htm

van Leeuwen, T. (2008). Discourse and practice: New tools for critical discourse analysis. Oxford: Oxford University Press.

Waitzkin, H. (1989). A critical theory of medical discourse: Ideology, social control, and the processing of social context in medical encounters. Journal of Health and Social Behavior 30: 220-239.

Waitzkin, H. (1993). The politics of medical encounters: How patients and doctors deal with social problems. Cambridge, MA: Yale University Press.

Wodak, R. (2001). What CDA is about: A summary of its history, important concepts, and its developments. In R. Wodak \& M. Meyer (Eds.), Methods of Critical Discourse Analysis (pp. 1-13). London: Sage. 